\author{
Mohd Rizwanullah, \\ Associate Professor, Manipal University Jaipur, India \\ D ORCID ID 0000-0002-6270-5562 \\ email: rizwansal@yahoo.co.in \\ Salah Abunar, \\ University of Business \& Technology, Saudi Arabia \\ D ORCID ID 0000-0002-3756-338X \\ email: salah@ubt.edu.sa \\ Sayeeduzzafar Qazi, \\ Professor, University of Business \& Technology, Saudi Arabia \\ D ORCID ID 0000-0003-1458-3166 \\ email: sayeed@ubt.edu.sa
}

Correspondence email: sayeed@ubt.edu.sa

\title{
CUSTOMER SATISFACTION AND BEHAVIOUR AT RETAIL OUTLETS: AN ADAPTIVE FUZZY REGRESSION MODEL WITH LINGO BASED ANALYSIS
}

Abstract. Increasing rivalry for-profit or non-profit is pushing companies to devote more and more attention to pleasing consumers with excellent quality customer services. This study aims to develop a model to analyse customer behaviour in a retail store and provide accurate inference for decision making. Another critical objective for this research work is the adaptation of the faceted form of neuro-response, which is substituted by the Adaptive Fuzzy Logistic Regression Model (AFLRM). AFLRM has resulting benefits over Neuro-surface and Mean Demand Heuristic methods. A sample of 100 customers who visited or walked in the retails was used as a sample. Other than neuroresponse surfaces (NRSM) and The Mean Demand Heuristic models (MDSM), the present study has accustomed a generalized form known as Adaptive Fuzzy Linear Regression Model (AFLRM) to deliver the benchmark for former models and give the highest level of accuracy for future behaviour of a customer. LINGO based Markovian analysis has also been used with the above model to understand the behaviour of the system under study. The significance of service and product attributes is implicitly derived via the fuzzy regression model for customer satisfaction measurement. It is observed that the critical gap between the quality of product and services and Customer Satisfaction is Product/Service Satisfaction, Motivation and Buying Experience, and Credibility and Security. The authors' finding indicates that the effort of listening to the customer's voice should be more critical. Result analysis based on computational results concerning the questionnaire for measuring the customer behaviour and the system validates the model under study. Appropriate, useful with reliable action plans for every critical product and service aspect can be developed by applying the adaptive regression methodology to control the quality of service or managing the customer satisfaction, thereby providing executives with a competitive gain. Also explored the behaviour of the system, i.e., whether the customer will move to the new retail outlets or they will remain in the same state by using the LINGO based software program model.

Keywords: heuristic, fuzzy, Markov process, retail customer, customer behaviour, LINGO, ISM.

Introduction. At present of rising rivalry with profit-centric is pressing businesses to devote even more attention to pleasing consumers, mainly concentrating actively on customer services. In the current market environment, quality of products and services are necessary critical factors for enterprises to survive in the system. The anticipated quality and service of consumers are not only the touchable segment but enhancing the professed goods and quality service in the practice of buying. Many businesses begin to search for Customer Satisfaction Quality because of the abiding competitive gain.

Cite as: Rizwanullah, M., Abunar, S., \& Qazi, S. (2020). Customer Satisfaction and Behaviour at Retail Outlets: an Adaptive Fuzzy Regression Model with LINGO Based Analysis. Marketing and Management of Innovations, 2, 275-285. http://doi.org/10.21272/mmi.2020.2-20 
M., Rizwanullah, S., Abunar, S., Qazi. Customer Satisfaction and Behaviour at Retail Outlets: an Adaptive Fuzzy Regression Model with LINGO Based Analysis

The globalization of the Indian economy concerning Retail industry displays its significant role in the international market. Many of the retail businesses face order variations and complicated service and quality-related issues. To fulfil customer's needs and make available better goods and services, the evaluation of the Customer Fulfilment concert is critical. If the customers are not satisfied with the goods and services at the precise period, it is required, this may have expensive consequences, such as lack of sales, customers displeasure and market survival. Customer satisfaction is one of the main areas in the performance/functioning index of the retail industry. Other key areas include retail management, stock/inventory control system, multi-facilities available, Pricing \& Product Value, security and credibility. Too many variables may influence consumer loyalty. Foster (1997) points out that the attribute value rating has several disadvantages, the most notable of which being that not everything that a customer feels being relevant affects his or her happiness and retainment. He has also proposed that computing the strength of consumer desires and demands is the capacity to take benefit of the significance of attributes.

The research tries to search for the potential distance between product quality, services and Patron Fulfilment in the Retail Outlets. They are using survey data obtained from a population to check some possible gaps of customers in Jaipur Retail outlets and find provision for the gaps and future behaviour of customers based on the results of the adaptive fuzzy regression model. Managers would then remove the gap between the vital aspects of top management, working staff and customers, and minimize costs, and increase running efficiency through these acts. In the second part of the study, A Lingo based Markovian analysis model is developed to estimate the behaviour of the system in terms of probability, i.e. whether the customer will remain to stay in system (market) or opt another system.

Literature Review. The study reviewed numerous secondary surveys on customer satisfaction and system behaviour/performance. Weitz \& Jap (1995), delivering superior consumer experience and loyalty is essential to a company's strategic advantage. Antony et al. (2004) focused on quality efficiency, and consumer loyalty is undeniably the key indicators of financial success with different channels, even in the service industry. Wes, Brockett \& Golden (1997) highlighted the neural networks methodology and its evaluation relative to statistical methods. They modelled the consumer judgement and decision-making using simulation application. Also proved that neural network-based model for predicting consumer choice is superior to the traditional statistical approach. Bertels et al. (1999) presented the classification models for the performance evaluation of the companies based on numerical criteria as managerial and organizational variables. Kuo (2001) focused on sales forecasting using ANN. He described the fuzzy neural network with initial weights generated by the genetic algorithm (GFNN) concerning marketing experts. Matzler et all (2004) argued that consumer service raises client engagement, reduces market volatility, improves cross-buying and enhances favourable word of mouth. Hansemark \& Albinsson (2004) also highlighted that customer satisfaction directly affects customer retaining and firm market segment. Many experimental studies have proved the positive correlation/association between profitability and customer satisfaction. Lawson \& Montgomery (2006) reviewed the application of logistic regression in modelling data based on customer satisfaction feedback. Asai, Tanaka \& Uegima (1982) focused on linear regression analysis with fuzzy behaviour of the system. Gronholdt \& Martensen (2005) studied data on customer satisfaction with a comparative study of regression analysis and ANNs. Yay \& Akinci (2009), Kwong, Wong \& Chan (2009) developed a model of generating customer satisfaction of new product development using the approach of neuro-fuzzy. Youn, \& Gu (2010), described the sorting of patients based on their evaluation of hospital outcomes: Rana et all (2015) determined the depending factors of customer satisfaction of retail chains in Bangladesh. The model developed to give the outcomes of measurement factors as responsiveness, product quality, physical design and pricing policies. Yilmaz \& Belbag (2016) developed a prediction model to determine the behaviour of consumer purchase of remanufactured products with logistic regression. They found the factors affecting the consumer behaviour of such products are low prices, company reliability and inferences that product promotion changes 
M., Rizwanullah, S., Abunar, A., Qazi. Customer Satisfaction and Behaviour at Retail Outlets: an Adaptive Fuzzy Regression Model with LINGO Based Analysis

consumer behaviour from no purchasing to purchasing remanufactured products, labelled about the customer satisfaction used as satisfaction attributes using neural network.

Bishop (1994) described the various application of neural networks in decision making and guided various future application. Deng, Chen \& Pei (2008) focused on service attributes when enhancing the service and customer services. He found the causal relationship between these attributes using BackPropagation Neural Network approach. Orhan et al. (2016) found that artificial neural networks (ANNs) overcome the boundaries of conventional statistical models which are noticeable in customer satisfaction research, and therefore, ANNs are best-suited to assessing the comparative significance of customer satisfaction features. Sharpen, et all (2018) concentrated on the existing market dynamics in automotivebased revenues and illustrated the latest strategy caused by digitization in this field. It also explains how Daimler, concerning consumer engagement and happiness, responds to these industry shifts with the impression of «Mercedes Me». Ban et alд (2019) described the customer's involvement exposed in the online review to sustain loyalty and customer satisfaction. The author sought to examine what the core characteristics of these primary attributes are and the systemic interaction. To clarify the hotel customer's perception and happiness, a frequency analysis, factor-analysis, network analysis and regression analysis were implemented. Vakulenko et al. (2019) found that in the present market situation, customer experience in e-retailing has become a competitive advantage. A quantitative methodology has been used to measure the perception and satisfaction level in Sweden. Zare et al. (2020) identified that grouping, particularly Kmeans, is one of the most useful data extracting techniques used in customer-based relationship management marketing for accurate prediction of consumer behaviour. When the degree of consumer engagement relies on behavioural factors such as their satisfaction, it will adversely impact the clusters of K-means and has no appropriate effects. In the present study, customer behavioural features - malicious feature - are considered in customer clustering, as well as a method for finding the optimum number of clusters and cluster centre initial values to achieve more accurate results. Sharma \& Klein (2020) argues that consumer engagement as vital for online retail group purchasing. The present work executes consumer-observed value, perceived confidence with satisfaction, and vulnerability to perceived risk to give a to offer a closer look at the consumer's intention to take part in online retail group purchasing.

Therefore, enhancing customer service in today's dynamic global marketplace is a crucial problem for business managers. Having this goal in mind, various business managers are always trying to define crucial quality and service characteristics that create customer satisfaction and loyalty to keep up to date with the contestants.

Methodology and Research Methods. The first optimization techniques under study are: 1) NeuroResponse Surface Methods (NRSM), and 2) the Adaptive Fuzzy Linear Regression Model (AFLRM) are using to solve the problem under study: Neuro-Response Surfaces (NRSM). Because of its robustness and excellent quantitative (statistical) support, the response surface method has become a common form of simulation-based optimization. Traditional RSM uses regression to fit the proposed model. It requires a meta-model to be taken for granted. NRSM does not presume a meta-model, as opposed to traditional RSM. Traditional RSM uses regression to fit the goal function. It includes a meta-model to be taken for granted. NRSM does not presume a meta-model, as opposed to conventional RSM. Neural networks achieve role fitting in NRSM. Its strength lies in the ability to match each board. Backpropagation is a wellknown algorithm uses in NRSM. The following are the steps to this algorithm.

Deduce neural network presented in Figure 1, the layer is known as «input» comprises of a finite number of nodes; typically, each decision variable is connected with one node. In the hidden/concealed layer, the number of nodes is a measure of the nonlinearity type of function has to be configured. The higher the nonlinearity of the function is the number of nodes required in the hidden type layer. The neural network calculates the so-called «weights» representing its meta-model. Let w(i,h) represent the weight from the $i^{\text {th }}$ input node to the HTH hidden node, and $x(h)$ is the weight from the HTH unknown type node 
M., Rizwanullah, S., Abunar, S., Qazi. Customer Satisfaction and Behaviour at Retail Outlets: an Adaptive Fuzzy Regression Model with LINGO Based Analysis

to the resulting/output node. In regression analysis based model fitting, the bias node is analogous to the constant value. Assume $p$ represents the number of pieces of data used to process neural networks. The available data for the $\mathrm{p}^{\text {th }}$ piece is $\overrightarrow{u_{p}}, y_{p}$ where $\overrightarrow{u_{p}}$, denotes a vector with «i» components.

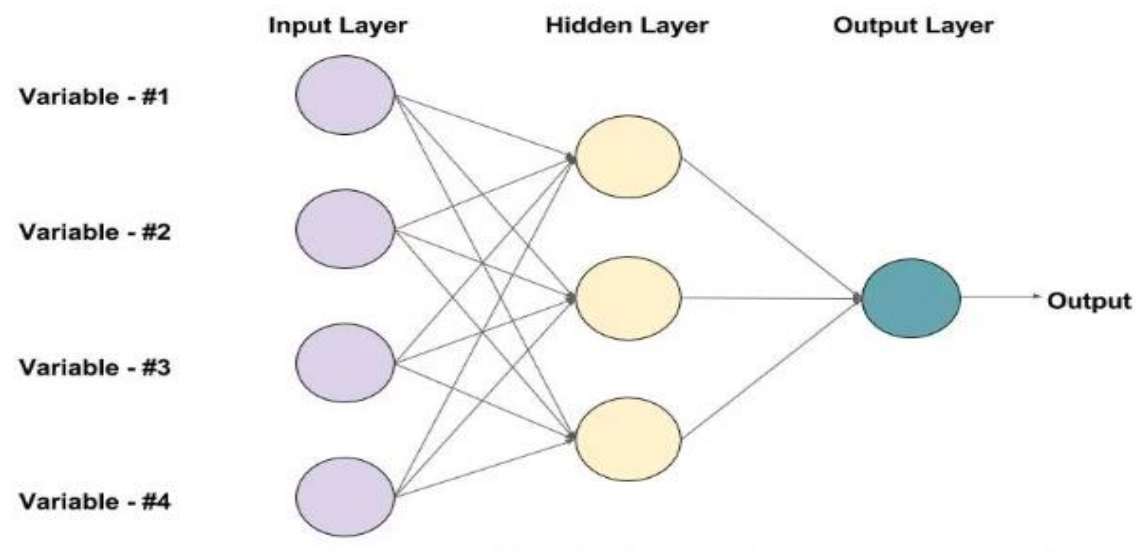

Figure 1. Neural network

Source: developed by the authors.

Step 1. In this step, firstly to arrange all the weights into small probable/random numbers. Then, set the sum of squared errors (SSE) value to the large number.

Step 2. At the hidden node, compute the value of output using the equation as:

$$
V_{p}^{*}(h)=\sum_{i=1}^{I} w(i, h) u_{p}(i)
$$

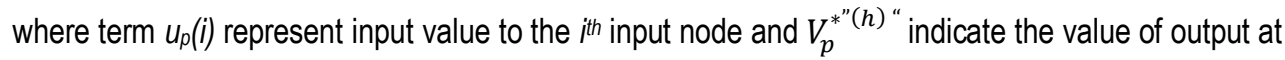
the hidden node $h$.

Step 3. Using the given sigmoid function, $V_{p}^{* \text { " }(h) \text { " }}$ calculate:

$$
V_{p}(h)=\frac{1}{\left(1+e^{-V_{p}^{*}(h)}\right)}
$$

Step 4. Now, it is required to calculate each output terms $Q_{p}$, using the formula given for $p=1,2$, $3, \ldots, n$, where «n» indicates the number of data pieces:

$$
O_{p}=b+\sum_{h=1}^{H} x(h) V_{p}(h) .
$$

Step 5. Update $w(l, h), b$, and $x(h)$ as: 


$$
\begin{aligned}
& b \leftarrow b+\mu \cdot \sum_{p=1}^{n}\left(y_{p}-O_{p}\right) . \\
& w(i, h) \leftarrow w(i, h)+\mu \sum_{p=1}^{n}\left\{\left(y_{p}-O_{p}\right) x_{h} v_{p}(h)\right\}\left(1-v_{p}(h)\right) u_{p}(i) . \\
& x(h) \leftarrow\left[x(h)+\mu \sum_{p=1}^{n}\left(y_{p}-O_{p}\right) v_{p}(h) .\right]
\end{aligned}
$$

Step 6. Calculating SSEnew.

Moderate the value of $\mu$. If $\left|S S E_{n e w}-S S E_{\text {old }}\right|<$ tolerance, then, stop. Otherwise, set the equation $S S E_{\text {old }}=\mathrm{SSE}_{\text {new }}$ and move to step 2.

Concept of Adaptive Fuzzy Logistic Regression Model. Fuzzy linear-regression theory: regression analysis is an approximation technique used to establish a smooth association between independent and dependent variables and applied to quantify the calculation of variance error. In this model, certain elements are characterized by fuzzy numbers where fuzzy-regression analysis is an extension of the traditional regression analysis model, Gronholdt et all (2005). There are two categories of Fuzzy Regression Analysis; the first is an analysis of possible regression based on conceptual possibility. Analysis of hypothetical regression utilizes fuzzy linear method as a regression model by reducing the overall imprecision of the predicted values for the dependent variables. It was suggested for the first time by Tanaka et al. (1982). The second group of the study of fuzzy regression adopts the strategy of fuzzy least squares models (FLSM) to reduce errors between the given outputs and the expected outputs.

Statistical Logistic Regression Theory. Statistical Logistic Regression is a statistical approach used to explain the relationship between multiple x's descriptive variables to a dichotomous dependent variable. Logistic regression may be used to forecast the outcome from a series of variables that can be constant, conditional, dichotomous or a combination of all of these. It is logistic regression requires no inference that the independent variables are distributed. It does not normally distribute within the increasing category, linearly connected or of equivalent variance. The dichotomous type-dependent variables can take the value 1 for the probability of success $P$, or the value of 0 with the probability of failure 1-P. This type of variable is called Bernoulli (or binary) variable, and distribution follow is Bernoulli's distribution. In Logistic regression model, the correlation between the predictor and response variables is not a linear type function. Instead, the logistic regression function is used that is the logit transformation.

$$
\begin{aligned}
& \operatorname{Ln}\left(\frac{1+P}{P}\right)=a+b_{1} x_{1}+b_{2} x_{2}+\cdots++b_{j} x_{j} \\
& \frac{P}{1-P}=e^{a+b_{1} x_{1}+b_{2} x_{2}+\ldots++b_{j} x_{j}} \\
& P=\frac{1}{1+=e^{-\left(a+b_{1} x_{1}+b_{2} x_{2}+\ldots++b_{j} x_{j}\right)}}
\end{aligned}
$$

where $P$ is the probability of $1, e$ is the basis of the natural logarithm (about 2.718), and $a$ and $b$ are the model parameters.

The Adaptive Fuzzy Logistic Regression Model (AFLRM). AFLRM is focused on the theoretical regression analysis model of Tanaka mentioned above, in which the answer variable $\mathrm{Y}$ is written as 
M., Rizwanullah, S., Abunar, S., Qazi. Customer Satisfaction and Behaviour at Retail Outlets: an Adaptive Fuzzy Regression Model with LINGO Based Analysis

$$
Y=A_{0} x_{0}+A_{1} x_{1}+A_{2} x_{2}+\ldots \ldots+A_{j} x_{j}+\ldots+A_{k} x_{k}
$$

$Y$ is the fuzzy performance, $x=\left[x_{1}, x_{2}, \ldots, x_{k}\right]^{T}$ is the input vector of independent variables with real value, and increasing coefficient of regression $A_{j}, j=0, \ldots, \mathrm{k}$ - asymmetrical with the triangular-fuzzy number with middle, $a_{j}$ and $1 / 2$-width $c_{j}, c_{j} \geq 0$ was presumed. Nevertheless, the potentialities methodology of Tanaka's fuzzy regression only extends to linear functions.

Since the dichotomous response variable defines the linearity functional relationship, appropriate transformation containing logit transformation must be done to reveal the secret linear relation. Before being nourished into a possible fuzzy linear regression model, data must be pre-treated, which is solved by using a linear programming method to yield a set of corresponding output in an interval form. The performance represents the probability logarithm for the occurrence of the case. Ultimately, by inverting the logarithm of the likelihood (logit) values, the output is converted back into the chance of the occurrence happening. It is presumed that the algorithm given here is the logarithm of the probability (logit) which is linearly connected to $x$ 's, the independent variables as it is performing the logit transformation. The steps for the algorithm adaptive model is as:

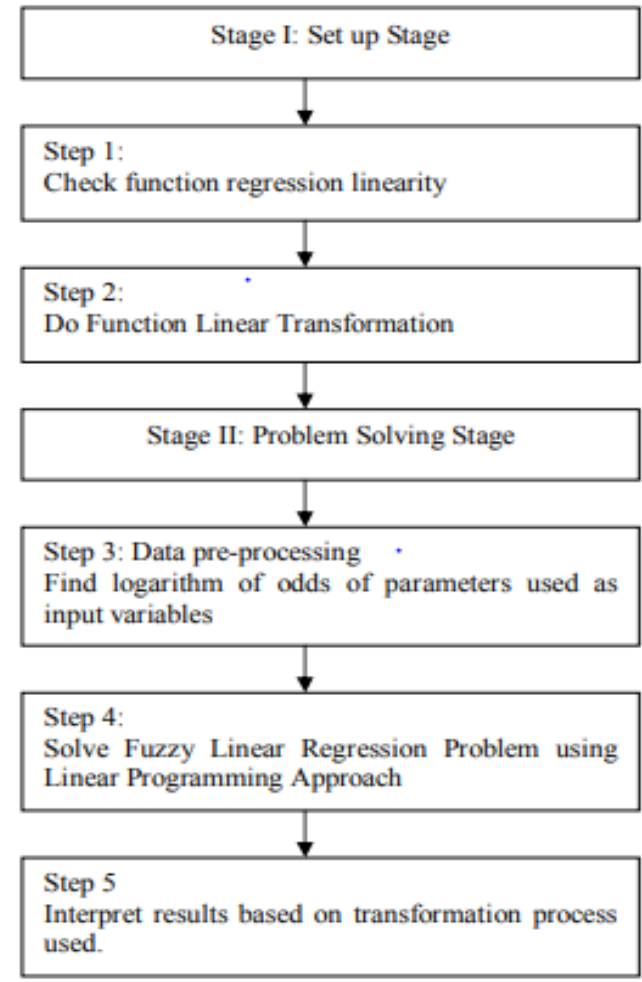

Source: developed by the authors

Figure 2. Adaptive Model Algorithm

The adaptive fuzzy logistic regression model (AFLRM) has been conducted with a sample set containing 100 customers based on survey data at retail stores with different standard questionnaires. It is describing the feasibility of application of AFLR algorithm in forecasting customer behaviour. The data- 
set $x=\left[x_{1}, x_{2}, \ldots, x_{k}\right]^{T}$ represents the input variables involving the Retail Store Evaluation, Product/Service Satisfaction, Motivation and Buying Experience, Product Use Satisfaction, Credibility and Security followed by 13 subfactors. The response variable is dichotomous explaining the customer behaviour concerning satisfaction of either having a positive or negative attitude.

There are a total of 13 diverse sets of input-variables based on the questionnaire were investigated, comprising:

Set 1 . Stores are conveniently located.

Set 2. Store hours convenience.

Set 3. Store atmosphere and decor

Set 4. Availability of proper selection of products.

Set 5. the lowest prices in the area.

Set 6. Product/Service Satisfaction.

Set 7. Motivation and Buying Experience.

Set 8. Any coupons or receive a discount.

Set 9. Product Use Satisfaction.

Set 10. Age-group.

Set 11. Ethnic group.

Set 12. Gender/sex.

Set 13. Credibility and Security.

The fundamental units of analysis in this study is the customers of Retail Outlets in Jaipur city to investigate their service situation, product quality, and many other factors with customer satisfaction. Informants were asked to base their answers on the most important 25 items that they focus on. The relevant questionnaires with objective using closed response requests and a six-point Likert scale ( $1=$ Very Unsatisfied to $6=$ Extremely Satisfied) was established. The questionnaires were collected from the customer who had visited or walking all around the retail outlet. We have collected 100 effective samples. Furthermore, by these informants, we arranged and selected the most important five variables of Customer Satisfaction. They are Retail Store Evaluation (purchase value, selection and service), Product/Service Satisfaction (Customer satisfaction with in-depth feedback), Motivation and Buying Experience (Product Knowledge, Courteousness, Product Background, Pricing \& Product Value), Product Use Satisfaction (Product use, attribute evaluation and satisfaction), and Credibility and Security(Security satisfaction, Waiting Time, Trust, parking) respectively. The results of the study showed that the retail industry has to investigate these quality degrees of customer satisfaction in order to understand the truly requirement of customers and obtain the critical index of continuous improvement. Thus, harmonized all the collected data of quality degree. Furthermore, the adaptive fuzzy regression model was applied to predictive modelling understand the future forecasting, i.e. behaviour of the customer with respect to the retail outlets quality service of an items. The critical service items will be found for improving the complete customer satisfaction.

Results. After comparing the AFLRM response to that of the above problem and comparing it with the NRSM and MDH. This study was operating the three approaches on a two-sellers setup. It is concluded that for solving these problems, AFLRM is quicker and efficient. The principal objective of this paper is the adaptation of the surface form of neuro-response, which is substituted by the Adaptive Fuzzy Logistic Regression Model. AFLRM has the resulting benefits over the other two (i.e., NRSM and MDH) methods:

1. No weights need to be allocated from the input node to the concealed node in AFLRM. Table 1 reflects the arithmetic value of both methods, which is roughly 1.

2. There are no hidden parameters that affect probabilistic scenarios, which therefore helps to optimize results performance.

3. AFLRM simplifies the situation and can expand to the tremendous Retail Outlets Networks issue. 
M., Rizwanullah, S., Abunar, S., Qazi. Customer Satisfaction and Behaviour at Retail Outlets: an Adaptive Fuzzy Regression Model with LINGO Based Analysis

Table 1. Computation Table

\begin{tabular}{|c|c|c|c|c|c|c|}
\hline \multicolumn{2}{|c|}{ Neuro-Response Surface Method } & \multicolumn{5}{|c|}{ Neuro-Response Surface Method } \\
\hline$w(i, h)(i=3)$ & $2,3,4$ & $\begin{array}{c}\text { Para- } \\
\text { meters }\end{array}$ & Values & $\begin{array}{l}\text { Para- } \\
\text { meters }\end{array}$ & & Values \\
\hline$\underset{I}{\operatorname{Up}}(\mathrm{i})$ & $10,12,15$ & $b_{1}$ & 2 & $x_{1}$ & 10 & \\
\hline$V_{p}^{*}(h)=\sum_{i=1} w(i, h) u_{p}(i)$ & 116 & $b_{2}$ & 3 & $\mathrm{x}_{2}$ & 12 & $\begin{array}{c}\text { Taking } \\
\text { approximately }\end{array}$ \\
\hline $\begin{array}{c}\boldsymbol{V}_{p}(\boldsymbol{h})=\mathbf{1} \\
\left(\mathbf{1}+\boldsymbol{e}^{-V_{p}^{*}(\boldsymbol{h})}\right) \\
\text { (Value of Sigmoid function) }\end{array}$ & $\begin{array}{c}1 /(1+4.186 \\
39 \mathrm{E}-51)=1 \\
\text { (appr.) }\end{array}$ & b3 & 4 & $\mathrm{X}_{3}$ & 15 & $\begin{array}{c}a=0 \\
\text { and } p=1\end{array}$ \\
\hline
\end{tabular}

Source: developed by the authors.

Markov-Chain approach is a common approach used in modelling the random variables over time. The simple concept is to think about the device at each point in time as being inside one of a distinct set of states. System behaviour is defined by a transition probability matrix that gives the likelihood that the system will move from one given state to another specified state. Some example situations are:

Table 2. Explanation of analysed situations

\begin{tabular}{ccc}
\hline System & States & Cause of Transition \\
\hline Customer brand switching & $\begin{array}{c}\text { Brand of product most recently } \\
\text { purchased by the consumer } \\
\text { Amventory System }\end{array}$ & $\begin{array}{c}\text { Customer changes mind, } \\
\text { advertisement }\end{array}$ \\
& Amount of inventory on hand & Orders for new material, demands \\
\hline
\end{tabular}

Source: developed by the authors.

One interesting issue is determining the system's long-term, steady-state probabilities. If we undertake the system can achieve equilibrium, then the chance of leaving an individual state must be genuine, equal to the chance of arriving in that state. It is redefining: Rate $\mathrm{In}=$ Rate Out Principle (RIRO. If let:

$\pi i=$ the steady-state probability of being in state $\mathrm{i}$, and $p i j=$ the transition probability of moving from state $i$ to $j$.

Then, by our RIRO assumption, for each i:

$$
\sum_{j \neq i}\left(p_{j} p_{j i}\right)=\pi_{i}\left(1-p_{j j}\right)
$$

From the above, then obtained:

$$
\pi_{i}=\sum_{j}\left(\pi_{j} p_{j i}\right)
$$

It brings us «n» number of equivalences to answer for the probability of «n» unknown in steady-state. Inappropriately, this system turns out to be not of complete rank. Therefore, there is not a unique solution. To assurance a compelling set of likelihoods, the researcher must make use of one final condition, the sum of the probabilities must be 1. Case Study suppose a new retail outlets/place like Wall Mart is likely to be introduced and study concerned about whether that market will be cleaned up. It will be competing against three other existing Outlets (Reliance, Big Bazaar and Vishal Mega Mart). As a consequence of a 
M., Rizwanullah, S., Abunar, A., Qazi. Customer Satisfaction and Behaviour at Retail Outlets: an Adaptive Fuzzy Regression Model with LINGO Based Analysis

small- assessment market and interviews with consumer's acquainted with all four retail outlets, then the following transition-matrix w.r.t purchase obtained:

Table 3. Purchase Transition Matrix

\begin{tabular}{cccccc}
\hline \multicolumn{5}{c}{ Subsequent -purchase } \\
\hline & New Retail & Reliance & Big Bazaar & Vishal Mega \\
Prev.- Purchase & Outlet (A) & (B) & (C) & Mart (D) \\
& New Retail Outlet (A) & 0.75 & 0.1 & 0.05 & 0.1 \\
& Reliance (B) & 0.4 & 0.2 & 0.1 & 0.3 \\
& Big Bazaar (C) & 0.1 & 0.2 & 0.4 & 0.3 \\
& Vishal Mega Mart (D) & 0.2 & 0.2 & 0.3 & 0.3 \\
\hline
\end{tabular}

Source: developed by the authors.

In this matrix, our new retail outlet is A. For instance, the matrix interpretation is if somebody recently purchased from $A$, then his next purchase of this product will also be from A with probability 0.75 . Similarly, someone who recently bought from $B$ would with likelihood 0.3 buy next from $D$. A partner who observed at this matrix said, - Aha, one should believe outlet A to get $75 \%$ of the souk/market in the long run. Do you think your partner is correct? LINGO Based Programme for Markov Chain Model Under Study. SETS: this model has 4 states and will reach equilibrium steady-state over a period.

Table 3. The Solution: feasible solution obtained at iteration no. 3

\begin{tabular}{cccc}
\hline Value & Variable & Value & Variable \\
\hline 0.1000000 & TNPROB $(P, S)$ & 0.4000000 & TNPROB $(R, R)$ \\
0.4000000 & TNPROB $(\mathrm{Q}, \mathrm{P})$ & 0.3000000 & $\operatorname{TNPROB}(\mathrm{R}, \mathrm{S})$ \\
0.2000000 & TNPROB $(\mathrm{R}, \mathrm{R})$ & 0.2000000 & $\operatorname{TNPROB}(\mathrm{S}, \mathrm{P})$ \\
0.1000000 & TNPROB $(\mathrm{Q}, \mathrm{R})$ & 0.2000000 & $\operatorname{TNPROB}(\mathrm{S}, \mathrm{Q})$ \\
0.3000000 & TNPROB $(\mathrm{P}, \mathrm{S})$ & 0.3000000 & $\operatorname{TNPROB}(\mathrm{S}, \mathrm{R})$ \\
0.1000000 & TNPROB $(\mathrm{R}, \mathrm{P})$ & 0.3000000 & $\operatorname{TNPROB}(\mathrm{S}, \mathrm{S})$ \\
0.2000000 & TNPROB $(\mathrm{R}, \mathrm{Q})$ & & \\
\hline
\end{tabular}

Source: developed by the authors

Therefore, it is observed that the long-term share of our new outlet $A$ would be about $47.5 \%$ of the market, that is substantially smaller than the $75 \%$ expected share (Table 3 ).

Conclusion. This study presented Adaptive fuzzy regression that integrates the five-factors theory. The significance of service and product attributes is implicitly derived via the fuzzy regression model for customer satisfaction measurement. It is observed that the critical gap between the quality of product \& services and Customer Satisfaction is Product/Service Satisfaction, Motivation and Buying Experience and Credibility and Security. Our finding also indicates that the effort of listening to customer voice should be more critical. The study finds the apparent gap between product and service quality and customer satisfaction. Authors have testes the projected gaps using data collected from a group of customers in different retail outlets and find provision for the quality gaps based on the results of the Adaptive fuzzy model with the help of neuro-solution 6.0 software. Therefore, Relevant, efficient and accurate action plans may be obtained for each essential product and service feature by using the adaptive regression method to customer satisfaction control or service quality control and offering strategic edge for managers. This study also identifies the behaviour of the system, i.e. whether customer will move to the new retail outlets or they will remain in the same state by using the LINGO based software program model. While finding the interface between consumer satisfaction and decision behaviour at retail outlets come not without limitation. The present research work is no exception to this collective experience. One of the limitations 
M., Rizwanullah, S., Abunar, S., Qazi. Customer Satisfaction and Behaviour at Retail Outlets: an Adaptive Fuzzy Regression Model with LINGO Based Analysis

is the biased nature of respondents, which justify the validity of the variables. The study is limited to lesser sample size, can be further extended to larger samples to reflects the diversity of the different region. Further study required to introduce the model's diversity using fuzzy and stochastic environments of the present research. The present research is considered a ground for future research.

Authors Contributions: conceptualization: M. R., S. Q.; methodology: M. R., S. A.; resources and data curation: M. R.; writing original draft preparation: M. R., S. Q.; writing review and editing: S. A., S. Q.; supervision: S. A., S. Q. ; final draft review: M. R, S. A., S. Q.

\section{References}

Antony, J., Antony, F. J., \& Ghosh, S. (2004). Evaluating service quality in a UK hotel chain: a case study. International Journal of Contemporary Hospitality Management, 16(6), 380-384. [Google Scholar] [CrossRef]

Asai, H. T. S. U. K., Tanaka, S., \& Uegima, K. (1982). Linear regression analysis with fuzzy model. IEEE Trans. Systems Man Cybern, 12, 903-907. [Google Scholar]

Ban, H. J., Choi, H., Choi, E. K., Lee, S., \& Kim, H. S. (2019). Investigating key attributes in experience and satisfaction of hotel customer using online review data. Sustainability, 11(23), 6570. [Google Scholar] [CrossRef]

Bertels, K., Jacques, J. M., Neuberg, L., \& Gatot, L. (1999). Qualitative company performance evaluation: Linear discriminant analysis and neural network

Bishop, C. M. (1994). Neural networks and their applications. Review of Scientific Instruments, 65(6), $1803-1832$ https://doi.org/10.1063/1.1144830. [Google Scholar] [CrossRef]

Deng, W. J., Chen, W. C., \& Pei, W. (2008). Back-propagation neural network based importance-performance analysis for determining critical service attributes. Expert Systems with Applications, 34(2), 1115-1125. [Google Scholar] [CrossRef]

Foster, D.C. (1997). Neural net analysis ferrets out-totally satisfied customers. Marketing News, 31(22), 17-18. [Google Scholar]

Hansemark, O. C., \& Albinsson, M. (2004). Customer satisfaction and retention: the experiences of individual employees. Managing Service Quality: An International Journal.[Google Scholar] [CrossRef]

Kuo, R.J. (2001). A sales forecasting system based on fuzzy neural network with initial weights generated by genetic algorithm. European Journal of Operational Research, 129(3), 496-502. [Google Scholar] [CrossRef]

Kwong, C. K., Wong, T. C., \& Chan, K. Y. (2009). A methodology of generating customer satisfaction models for new product development using a neuro-fuzzy approach. Expert Systems with Applications, 36(8), 11262-11270. [Google Scholar] [CrossRef]

Lawson, C., \& Montgomery, D. C. (2006). Logistic regression analysis of customer satisfaction data. Quality and Reliability Engineering International, 22(8), 971-984. [Google Scholar] [CrossRef]

Matzler, K., Bailom, F., Hinterhuber, H. H., Renzl, B., \& Pichler, J. (2004). The asymmetric relationship between attribute-level performance and overall customer satisfaction: a reconsideration of the importance-performance analysis. Industrial marketing management, 33(4), 271-277. [Google Scholar] [CrossRef]

Oralhan, B., Kumru, U. Y. A. R., \& Oralhan, Z. (2016). Customer satisfaction using data mining approach. International Journal of Intelligent Systems and Applications in Engineering, 63-66. [Google Scholar] [CrossRef]

Rana, S. S., Osman, A., \& Islam, M. A. (2014). Customer satisfaction of retail chain stores: Evidence from Bangladesh. Journal of Asian Scientific Research, 4(10), 574. [Google Scholar]

Scherpen, F., Draghici, A., \& Niemann, J. (2018). Customer Experience Management to Leverage Customer Loyalty in the Automotive Industry. Procedia-Social and Behavioral Sciences, 238, 374-380. [Google Scholar] [CrossRef]

Sharma, V. M., \& Klein, A. (2020). Consumer perceived value, involvement, trust, susceptibility to interpersonal influence, and intention to participate in online group buying. Journal of Retailing and Customer Services, 52, 6969-6989. [Google Scholar] [CrossRef]

Vakulenko, Y., Shams, P., Hellström, D., \& Hjort, K. (2019). Online retail experience and customer satisfaction: the mediating role of last mile delivery. The International Review of Retail, Distribution and Consumer Research, 29(3), 306-320. [Google Scholar] [CrossRef]

Weitz, B. A., \& Jap, S. D. (1995). Relationship marketing and distribution channels. Journal of the academy of Marketing Science, 23(4), 305-320. [Google Scholar] [CrossRef]

West, P. M., Brockett, P. L., \& Golden, L. L. (1997). A comparative analysis of neural networks and statistical methods for predicting consumer choice. Marketing Science, 16(4), 370-391. [Google Scholar] [CrossRef]

Yay, M., \& Akinci, E. D. (2009). Application of ordinal logistic regression and artificial neural networks in a study of student satisfaction. Cypriot Journal of Educational Sciences, 4(7), 58-69.

Yilmaz, K. G., \& Belbag, S. (2016). Prediction of consumer behavior regarding purchasing remanufactured products: a logistics regression model. International Journal of Business and Social Research, 6(2), 01-10. [Google Scholar] 
M., Rizwanullah, S., Abunar, A., Qazi. Customer Satisfaction and Behaviour at Retail Outlets: an Adaptive Fuzzy Regression Model with LINGO Based Analysis

Youn, H., \& Gu, Z. (2010). Predict US restaurant firm failures: The artificial neural network model versus logistic regression model. Tourism \& Hospitality Research, 10(3), 171-187. [Google Scholar] [CrossRef]

Zare, H., \& Emadi, S. (2020). Determination of Customer Satisfaction using Improved K-means algorithm. Soft Compututing. [Google Scholar] [CrossRef]

Мохд Різватуллах,

доцент, Університет Маніпал, Індія

Салах Абунар,

Університет бізнесу та технологій, Саудівська Аравія

Сайедуззафар Казі

професор, Університет бізнесу та технологій, Саудівська Аравія

Задоволеність споживачів та їх поведінка у роздрібній-торгівлі: адаптивна регресійна модель та LINGO аналіз

Зростаюча конкуренція у сфері роздрібної торгівлі обумовлює необхідність підвищення якості обслуговування споживачів. Головною метою статті $є$ розроблення економіко-математичної моделі для аналізу факторів, що впливають на поведінку та прийняття рішень споживачами у роздрібно-тореівельній мережі. Авторами запропоновано удосконалити модель нейро-поверхні та використовувати адаптивну Fuzzy-регресійну модель (AFLRM). У статті систематизовано переваги адаптивної Fиzzу-регресійної моделі перед еврестичним методом нейро-поверхні. Емпіричне дослідження проведено на основі панельних даних, сформованих для вибірки зі 100 споживачів роздрібноторгівельної мережі. Для аналізу панельних даних використано модель нейро-поверхні (NRSM), еврестичну модель середнього попиту (MDSM), а також адаптивну Fuzzy-регресійну модель. Наголошено, що адаптивна Fuzzy-регресійна модель забезпечує найвищу точність результатів прогнозування поведінки споживачів. У свою чергу, LINGO модель застосовано для інтерпретаиії поведінки досліджуваної системи. Результати даної моделі дозволили визначити поведінку системи та лояльність споживачів до певного магазину. Авторами відмічено, що вплив атрибутів послуг та товарів неявно описується адаптивною Fuzzy-регресійною моделлю. При иьому встановлено, що є критичний розрив між лояльністю клієнтів та якістю продуктів (послуг) на який мають статистично значущий вплив такі параметри як: рівень задоволення товаром чи послугами, рівень мотивації, купівельний досвід, рівень довіри та впевненості у якості товару. Визначено, що ефьективність маркетингової програми промоиії відповідного товару (послугу) повинна визначатись на основі результатів оцінювання рівня лояльності та задоволення споживачів із використанням Fuzzyрегресійної моделі. Одним із обмежень даного дослідження $\epsilon$ незначна вибірка респондентів та їх регіональна приналежність. Узв'язку з цим у подальшому необхідним $є$ аналіз більшої вибірки респондентів із різних міст Саудівської Аравії.

Ключові слова: евристика, нечіткий, процес Маркова, кінцевий споживач, споживча поведінка, LINGO, ISM

Manuscript received: 07.02.2020

(C) The author(s) 2020. This article is published with open access at Sumy State University 